\title{
The Physical Fitness Analysis of Handball Female Athletes of Central Java
}

\author{
Shamarah Hanin Khanza ${ }^{1}$, Muchlisin ${ }^{2}$, Anggit Wicaksono ${ }^{3}$ \\ \{shamarahhanin7@gmail.com ${ }^{1}$, muchlisin.unwahas@gmail.com ${ }^{2}$, anggit_w@mail.unnes.ac.id ${ }^{3}$ \} \\ Universitas Negeri Semarang, Semarang, Indonesia ${ }^{1,3}$ \\ Universitas Wahid Hasyim, Semarang, Indonesia ${ }^{2}$
}

\begin{abstract}
This study aims to determine the physical abilities of Central Java Women's Handball Athletes who are prepared to face the XX 2021 PON event which will be held next October. The method used in this research is a survey method with data collection techniques using tests. The subjects in this study were all female athletes of Handball in Central Java who were prepared to face PON with a total of 16 female athletes. The results of a series of tests showed that the average sit-up test of 65 times was in the very good category with 14 athletes in the very good category and 2 athletes in the moderate category, an average of $40 \mathrm{~cm}$ of vertical jumps being in the good category with 1 athlete is in the excellent category and 15 athletes are in the good category, an average Illinois Agility Run test of 18 seconds is in the moderate category, an average Medicine Ball Push test of $3 \mathrm{~m} / \mathrm{s}$ is in the moderate category, and an average an average bleep test of level $8 \mathrm{VO} 2 \max 40$ is in the very good category.
\end{abstract}

Keywords: physical components, handball athletes, central java

\section{Introduction}

Handball is a game that has a fast rhythm and involves two teams with a player composition consisting of 7 people, each of which has tasks such as passing, throwing, catching, and dribbling using arbitrary hands trying to score goals against the opponent's goal (Lutan: 1998) . In Handball matches, each team is required to score as many goals against the opponent as possible during the match time so that they can outperform the opposing team. In addition, every athlete is required to be able to master various basic techniques that exist in the handball game itself. Every handball athlete is also required to have the speed of movement to support his performance in competitions and to have good physical condition. Handball sport has a match duration of 30 minutes per round. Break Time is 10 minutes in each half.

To improve the quality of an athlete in improving physical and spiritual health, one must instill a high discipline and sportsmanship, as well as develop sports achievements that can generate pride for the country. Athletes must be really active in training and maintain their physical condition before and after competing so that when competing they can get the maximum results that are produced during training. Physical condition plays an important role in handball game, because every player is required to run frequently and make continuous movements. To be able to play good handball, athletes must have good physical abilities. The elements of physical condition include endurance, speed, strength, agility, muscle power, flexibility, balance, coordination, accuracy, and reaction. (Ministry of Health of the Republic 
of Indonesia in Nala: 2002). According to Tanwar, B (2103), the dominant physical conditions in cross-season are speed, strength, flexibility, power, agility, and endurance. Apart from the physical condition components, tactics and strategy are also important elements in the game of handball . Fostering physical condition is a way that must be done in an effort to achieve good physical condition, knowing the potential and developing it to the maximum is a capital that can be used as a benchmark in making a basis for carrying out physical coaching from where to start (Latuheru: 2018). The importance of physical tests on handball athletes as supporting performance for an athlete.

\section{Method}

This type of research uses a survey method with quantitative descriptive analysis. This study has 5 variables, namely; 1) abdominal muscle strength 2) leg power, 3) agility, 4) arm power, 5) aerobic endurance. The abdominal muscle strength test is done with sit ups for 1 minute. The leg power test is done with a vertical jump. The agility test was carried out with the Illinois. Arm power test is done with a medicine ball. Endurance tests were carried out using MFT (Multi Stage Fitness). The population of the study was 16 female handball athletes in Central Java. The sampling technique uses the total population, which means that all populations are used as research samples. The research instrument used a valid and reliable physical fitness test. The data analysis technique used descriptive statistics.

\section{Result and Discussion}

The following table presents the physical fitness results of Central Java Women's Handball athletes:

Table 1. Java women handball athletes physical fitness

\begin{tabular}{cccccc}
\hline NO & Sit Up & Illinois & $\begin{array}{c}\text { Vertical } \\
\text { Jump }\end{array}$ & Medicine & MFT \\
\hline 1 & 70 & 18.29 & 34 & 2.68 & 8.4 \\
2 & 59 & 17.98 & 38 & 3.50 & 8.6 \\
3 & 61 & 17.22 & 42 & 3.37 & 9.8 \\
4 & 96 & 19.41 & 40 & 2.83 & 9.1 \\
5 & 56 & 18.17 & 39 & 2.44 & 7.6 \\
6 & 68 & 18.98 & 36 & 2.97 & 8.3 \\
7 & 46 & 18.62 & 41 & 2.84 & 7.5 \\
8 & 62 & 17.70 & 46 & 3.89 & 8.7 \\
9 & 107 & 18.45 & 49 & 3.75 & 9.5 \\
10 & 55 & 17.29 & 40 & 2.76 & 9.1 \\
11 & 53 & 18.18 & 51 & 2.97 & 7.5
\end{tabular}




\begin{tabular}{cccccc}
12 & 59 & 17.31 & 40 & 3.06 & 8.6 \\
13 & 75 & 18.89 & 36 & 3.40 & 8.4 \\
14 & 72 & 17.82 & 39 & 2.73 & 8.8 \\
15 & 58 & 18.77 & 39 & 2.82 & 6.4 \\
16 & 45 & 21.77 & 36 & 3.81 & 4.4 \\
\hline Amount & 1042 & 295 & 646 & 50 & 131 \\
Mean & 65 & 18 & 40 & 3 & 8 \\
\hline
\end{tabular}

Based on the results of measuring the physical components of the female handball athletes in Central Java, it shows that they have a good physique. This means that during the training program from the coach, the athletes really do it. Therefore, from the results of measuring the physical components as expected. The physical test consists of 5 components, namely the sit up test, illinois, vertical jump, medicine, and MFT (Multi Stage Fitness). With a very good situp test for strength and endurance of the abdominal muscles, it can support the shoting technique. the illinois test is very good at measuring the body's ability to change direction quickly when moving without losing balance, this can support feinting techniques (deceptive movements) when attacking. The vertical jump test is very good for measuring the power of the leg muscles, it can support the jump shot technique. Medicine tests can measure the strength of the arm's power and can support passing and shoting techniques. The MFT (Multi Stage Fitness) test is very good for endurance in athletes. Handball athletes must have good endurance because handball is a sport that runs continuously for 30 minutes and has to hit the ball into the opponent's goal as much as possible until the game time runs out, this requires good endurance. Thus, as a handball athlete, he must maintain his physical condition so that it remains stable and does not decline. Athletes need to do physical ability training which refers to an exercise program that is carried out in a planned, progressive and systematic manner so that their physical abilities can increase. By carrying out tests and measurements of physical abilities on athletes that can find out the results during the training they are running, and also athletes are better prepared to face the matches that will be held at the specified time.

The results of the sit-up test in the table show that the female handball athletes in Central Java with an average of 65 times for 1 minute are in the very good category, 14 athletes are in the very good category and 2 athletes are in the moderate category. The results from the Illinois test with an average of 18 seconds are in the moderate category. The results of the vertical jump test with an average of $40 \mathrm{~cm}$ are in the good category, it is found that 1 athlete is in the very good category and 15 athletes are in the good category. The results of the medicine ball test with an average of $3 \mathrm{~m} / \mathrm{s}$ fall into the moderate category. The results of the MFT (Multi Stage Fitness) test with an average level of 8 VOmax 40 are in the excellent category.

\section{Conclusion}

From the results of the above research that the physical abilities of the Central Java women's handball athletes have a good average physical component. During the training program from the trainer, the results will be seen on the test results, which consist of a physical component test, namely the sit-up test, the Illinois test, the vertical jump test, the 
medicine test, and the MFT test. it can improve the ability to do handball technique. every athlete must have a sense of responsibility and discipline to train in order to be ready for the future and ready to support performance.

\section{References}

[1] Tanwar B. Prediction of playing ability of university level handball players in relation to their motor ability and kinthropometric variables. Int J Soc Sci Interdiscip Res. 2013;2(1):172-93.

[2] Muhlisin dan Pranawa, Joko. Metode dan Dasar-Dasar Handball (Method and Basics Handball). Paramitha ST, editor. Semarang; 2016.

[3] Waghmare AR, Surdi AD, Bondade AK. Study of Flexibility, Agility and Reaction Time in Handball Players. 2012;23-31.

[4] Widiastuti. Tes Dan Pengukuran Olahraga. Jakarta; 2015.

[5] Czerwinski, J. and Taborsky, F. Basic Handball. European Handball. Austria;1997.

[6] Mackenzie B. 101 Tests D’Évaluations. 2008. 229 p

[7] Clanton R, Dwight MP. Team Handball Steps to Success. Vol. 46, Sports Medicine. 1997. 168 p.

[8] Sajoto, M. Peningkatan \& Pembinaan Kondisi Fisik Dalam Olahraga. Dahara Prize. Semarang; 1988.

[9] Sumosardjuno. S. Petunjuk Praktis Kesehatan Olahraga. Jakarta: PT. Pustaka Karya Grafika Utama; 1987.

[10] Sharkey, Brian J. Kebugaran dan Kesehatan. Terjemahan Eri Desmarini Nasution. Jakarta: Raja Grafindo Persada;2003

[11] Handball I. International Handball Federation IX. Rules of the Game a) Indoor Handball. 2016;(July)

[12] Dr. Albertus Fenanlampir MP, AIFO, Faruq DMM. Tes dan Pengukuran Dalam Olahraga. Bendatu M, editor. Yogyakarta; 2015.

[13] Firdaus M, Zawawi MA, ... Menghadapi Pekan Olahraga Nasional tahun 2020: sejauh mana profil kondisi fisik atlet bola tangan Provinsi Jawa Tengah. J Sport J ... [Internet]. 2020;6(3):819-32. Available from: https://ojs.unpkediri.ac.id/index.php/pjk/article/view/15215

[14] Buku Tes Kebugaran Jasmani Indonesia. Formulir Tes Kebugaran Jasmani Indonesia (TKJI). Olahraga Kebugaran Jasm. 2010;1200:71-87.

[15] Purnomo E. Pengaruh Program Latihan terhadap Peningkatan Kondisi Fisik Atlet Bolatangan Porprov Kubu Raya. JSES J Sport Exerc Sci. 2019;2(1):29.

[16] Dawud VWGWAN, Hariyanto E. Survei Kondisi Fisik Pemain Sepakbola U 17. Sport Sci Heal [Internet]. 2020;2(4):224-31. Available from: http://journal2.um.ac.id/index.php/jfik/index

[17] Ministry of Health of the Republic of Indonesia in Nala: 2002 